\title{
Artepillin C (3,5-diprenyl-4-hydroxycinnamic acid) sensitizes LNCaP prostate cancer cells to TRAIL-induced apoptosis
}

\author{
EWELINA SZLISZKA ${ }^{1}$, GRZEGORZ ZYDOWICZ ${ }^{1}$, ELZBIETA MIZGALA ${ }^{2}$ and WOJCIECH KROL ${ }^{1}$ \\ Departments of ${ }^{1}$ Microbiology and Immunology and ${ }^{2}$ Family Medicine, \\ Medical University of Silesia in Katowice, Zabrze, Poland
}

Received March 21, 2012; Accepted May 18, 2012

DOI: $10.3892 /$ ijo.2012.1527

\begin{abstract}
Naturally occurring phenolic compounds have been shown to sensitize prostate cancer cells to tumour necrosis factorrelated apoptosis-inducing ligand (TRAIL)-induced apoptosis. TRAIL is a potent stimulator of apoptosis in cancer cells and an important immune effector molecule in the surveillance and elimination of developing tumours. However, many cancer cells are resistant to TRAIL-mediated death. In this study, we aimed to determine the mechanisms by which TRAIL resistance can be overcome in prostate cancer cells by 3,5-diprenyl-4-hydroxycinnamic acid (artepillin $\mathrm{C}$ ). Artepillin $\mathrm{C}$ is a bioactive component of Brazilian green propolis that possesses antitumour and chemopreventive activities. TRAIL-resistant LNCaP prostate cancer cells were treated with TRAIL and artepillin C. Cytotoxicity was measured by MTT and lactate dehydrogenase (LDH) assays. Apoptosis was detected using Annexin V-FITC staining by flow cytometry and fluorescence microscopy. Death receptor (DR) (TRAIL-R1/DR4 and TRAIL-R2/DR5) expression was analyzed using flow cytometry. Mitochondrial membrane potential $(\Delta \Psi \mathrm{m})$ was evaluated using DePsipher staining by fluorescence microscopy. The inhibition of NF- $\kappa \mathrm{B}$ (p65) activation was confirmed with the ELISA-based TransAM NF- $\kappa$ B kit. Caspase- 8 and caspase-3 activities were determined by colorimetric protease assays. The results showed that artepillin $\mathrm{C}$ sensitized the TRAIL-resistant LNCaP cells by engaging the extrinsic (receptor-mediated) and intrinsic (mitochondrial) apoptotic pathways. Artepillin C increased the expression of TRAIL-R2 and decreased the activity of $\mathrm{NF}-\kappa \mathrm{B}$. Co-treatment with TRAIL and artepillin C induced the significant activation of caspase- 8 and caspase-3, as well as the disruption of $\Delta \Psi \mathrm{m}$. These findings show that prostate cancer cells can be sensitized to TRAIL-mediated immunoprevention
\end{abstract}

Correspondence to: Professor Wojciech Krol, Department of Microbiology and Immunology, Medical University of Silesia in Katowice, Jordana 19, 41808 Zabrze, Poland

E-mail: wkrol@sum.edu.pl

Key words: artepillin C, green propolis, tumour necrosis factorrelated apoptosis-inducing ligand, apoptosis, prostate cancer, chemoprevention by artepillin $\mathrm{C}$ and confirm the role of phenolic compounds in prostate cancer immunochemoprevention.

\section{Introduction}

The induction of cancer cell-specific apoptosis via the activation of tumour necrosis factor-related apoptosis-inducing ligand (TRAIL) signalling has become an important focus of cancer research. TRAIL triggers apoptosis in cancer cells with no toxicity toward normal tissues $(1,2)$. Endogenous TRAIL plays an important role in immunosurveillance and defence against tumour cells. TRAIL-mediated apoptosis of pre-malignant or malignant cells represents an immune preventive mechanism against tumour initiation, formation and progression. TRAIL is expressed on the surface of T lymphocytes, natural killer cells, dendritic cells, neutrophils, monocytes or macrophages and can be cleaved into a soluble, secreted form (1-3). This death ligand induces apoptosis in cancer cells via a receptormediated pathway involving interactions with TRAIL-R1/ death receptor (DR)4 and/or TRAIL-R2/DR5. Stimulation of the death receptor system by TRAIL results in the recruitment of the adaptor molecule, Fas-associated death domain (FADD), to form the death inducing signalling complex (DISC), which subsequently activates caspase-8. Crosstalk between the extrinsic (receptor-dependent) and intrinsic (mitochondrialdependent) apoptotic pathways is linked by caspase- 8 . The activation of caspase- 8 directly causes the activation of the caspase cascade and cell death. Simultaneously, caspase- 8 leads indirectly to the activation of effector caspases through the cleavage of the $\mathrm{BH} 3$-interacting domain death agonist (Bid), along with the release of cytochrome $c$ and mitochondrial membrane potential ( $\Delta \Psi \mathrm{m})$ disruption (1-6). However, some cancer cells are resistant to TRAIL-induced cytotoxicity (7-11). This failure to undergo apoptosis has been implicated in the resistance of cancer cells to TRAIL surveillance and, therefore, in tumour development $(1-3,6)$. The expression of the death receptors and pro-apoptotic or anti-apoptotic proteins in cancer cells is involved in TRAIL resistance $(1,2,6)$. TRAIL-resistant prostate cancer cells can be sensitized to TRAIL-mediated apoptosis by certain phenolic compounds $(6,8,12-20)$.

Artepillin C (3,5-diprenyl-4-hydroxycinnamic acid) is the major biologically active phenolic component found in green propolis, which is collected from the plant Baccharis dracunculiforia in Southeastern Brazil (21-23). Artepillin C possesses 
antioxidant, antimicrobial, anti-inflammatory, antigenotoxic, anti-angiogenic and anticancer properties (24-36). The structure of this hydroxycinnamic acid derivative is presented in Fig. 1. Artepillin $\mathrm{C}$ exerts direct antiproliferative, cytotoxic and apoptotic effects on gastric, colon or lung cancer cells and inhibits the growth of transplanted solid human or mouse tumours in athymic and thymic mice, respectively (25). The role of natural phenolic compounds in cancer prevention has been confirmed in numerous laboratory and epidemiological studies (37-43).

Prostate cancer is one of the most commonly diagnosed cancers in men, the third leading cause of cancer-related mortality in Europe, and the second in the United States $(16,44)$. Chemopreventive intervention using dietary phenolics is an attractive option in prostate cancer due to its incidence, prevalence and disease-related morbidity and mortality (45).

Previous findings have demonstrated that the ethanolic extract of Brazilian green propolis (EEP) and its constituent, artepillin C, can help cells overcome TRAIL resistance and significantly augments the apoptotic activity of TRAIL in LNCaP prostate cancer cells (17). Artepillin C sensitizes prostate cancer cells to TRAIL-mediated immunoprevention, which confirms the potential role of this prenylated hydroxycinnamic acid derivative as a chemopreventive agent in prostate carcinogenesis. The aim of this study was to evaluate the mechanisms by which artepillin $\mathrm{C}$ affects the TRAIL-induced death signalling pathway in prostate cancer cells.

\section{Materials and methods}

Prostate cancer cell culture. The LNCaP human androgendependent prostate cancer cell line was obtained from the German Collection of Microorganisms and Cell Cultures (DSMZ, Braunschweig, Germany). The cells were grown in monolayer cultures at $37^{\circ} \mathrm{C}$ in a $5 \% \mathrm{CO}_{2}$ humidified incubator and were maintained in RPMI-1640 medium supplemented with $10 \%$ heat-inactivated fetal bovine serum (FBS), $4 \mathrm{mM}$ L-glutamine, $100 \mathrm{U} / \mathrm{ml}$ penicillin and $100 \mu \mathrm{g} / \mathrm{ml}$ streptomycin $(7,8,16,17)$. Reagents for cell culture were purchased from the PAA Cell Culture Company (Pasching, Austria).

Reagents. Artepillin C was provided by Wako Pure Chemicals (Osaka, Japan) as a natural component isolated from Brazilian green propolis. Artepillin $\mathrm{C}$ was dissolved in dimethyl sulphoxide (DMSO) to obtain the working concentrations. Soluble recombinant human TRAIL was purchased from PeproTech Inc. (Rocky Hill, NJ, USA). Human recombinant TRAIL-R1/Fc and TRAIL-R2/Fc chimera proteins, the general caspase inhibitor, Z-VAD-FMK, the caspase-8 inhibitor, Z-IETD-FMK, and the caspase-3 inhibitor, Z-DEVD-FMK, were obtained from R\&D Systems (Minneapolis, MN, USA).

Cytotoxicity assay. Cytotoxicity was measured by the 3-(4,5dimethyl-2-thiazyl)-2,5-diphenyl-2H-tetrazolium bromide (MTT) assay $(46,47)$. The MTT assay is based on the cleavage of the tetrazolium salt MTT to a blue formazan dye by viable cells. LNCaP cells $\left(2 \times 10^{5} / \mathrm{ml}\right)$ were seeded in a 96-well plate for $24 \mathrm{~h}$ before the experiments. The cells were then incubated with TRAIL (50-200 ng/ml) and/or artepillin C (50-100 $\mu \mathrm{M})$. After $24 \mathrm{~h}, 20 \mu \mathrm{l}$ of MTT solution $(5 \mathrm{mg} / \mathrm{ml})$ were added to

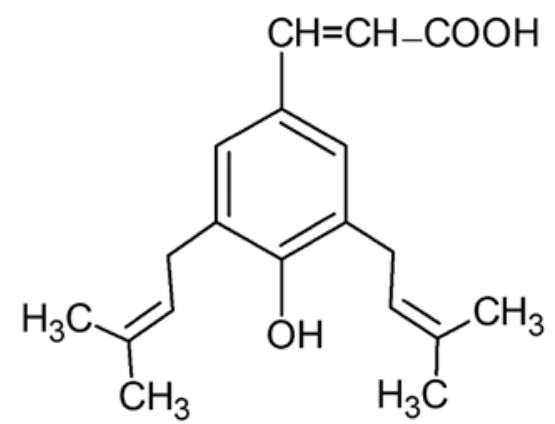

Figure 1. Chemical structure of artepillin C (3,5-diprenyl-4-hydroxycinnamic acid).

each well for $4 \mathrm{~h}$. The resulting blue formazan crystals were dissolved in DMSO. These reagents were purchased from Sigma Chemical Company (St. Louis, MO, USA). The controls included native cells and medium alone. Spectrophotometric absorbance was measured at a 550-nm wavelength using a microplate reader (ELx 800, Bio-Tek Instruments Inc., Winooski, VT, USA). The percentage cytotoxicity was calculated by the following formula: percentage cytotoxicity (cell death) $=[1-$ (absorbance value of experimental wells/absorbance value of control wells)]) $x 100 \%$.

Lactate dehydrogenase $(\mathrm{LDH})$ release assay. $\mathrm{LDH}$ is a stable cytosolic enzyme that is released upon membrane damage in necrotic cells. LDH activity was measured using a cytotoxicity assay kit (Roche Diagnostics GmbH, Mannheim, Germany) $(14,48)$. LNCaP cells were treated with TRAIL (50-200 ng/ $\mathrm{ml})$ and/or artepillin $\mathrm{C}(50-100 \mu \mathrm{M})$ for the indicated period of time. LDH released into the culture supernatants was detected with a coupled enzymatic assay, that results in the conversion of a tetrazolium salt into a red formazan product. Spectrophotometric absorbance was measured at a 490-nm wavelength using a microplate reader. Maximal release of LDH was obtained after treating the control cells with $1 \%$ Triton X-100 (Sigma) for $10 \mathrm{~min}$ at room temperature. The percentage of necrotic cells was expressed using the following formula: (sample value/maximal release) x100\%.

Detection of apoptosis by flow cytometry. Apoptosis was determined by flow cytometry using the Apoptest-FITC kit with Annexin V (Dako, Glostrup, Denmark). LNCaP cells $\left(2 \times 10^{5} / \mathrm{ml}\right)$ were seeded in 24 -well plates for $24 \mathrm{~h}$ prior to experimentation and then exposed to TRAIL (100 ng/ml) and/ or artepillin $\mathrm{C}(50-100 \mu \mathrm{M})$ for $24 \mathrm{~h}$. After this incubation, the cells were washed twice with phosphate-buffered saline (PBS) solution and resuspended in $1 \mathrm{ml}$ of binding buffer. The cell suspension $(500 \mu \mathrm{l})$ was then incubated with $5 \mu \mathrm{l}$ of Annexin V-FITC and $10 \mu \mathrm{l}$ of propidium iodide (PI) for $10 \mathrm{~min}$ at room temperature in the dark. The population of Annexin V-positive cells was evaluated by flow cytometry (BD FACScan; Becton-Dickinson Immunocytometry Systems, San Jose, CA, USA) $(15,49)$.

Detection of apoptosis by fluorescence microscopy. Apoptotic cells were quantified using the fluorescence microscopy method of the Apoptotic \& Necrotic \& Healthy Cells Quantification 

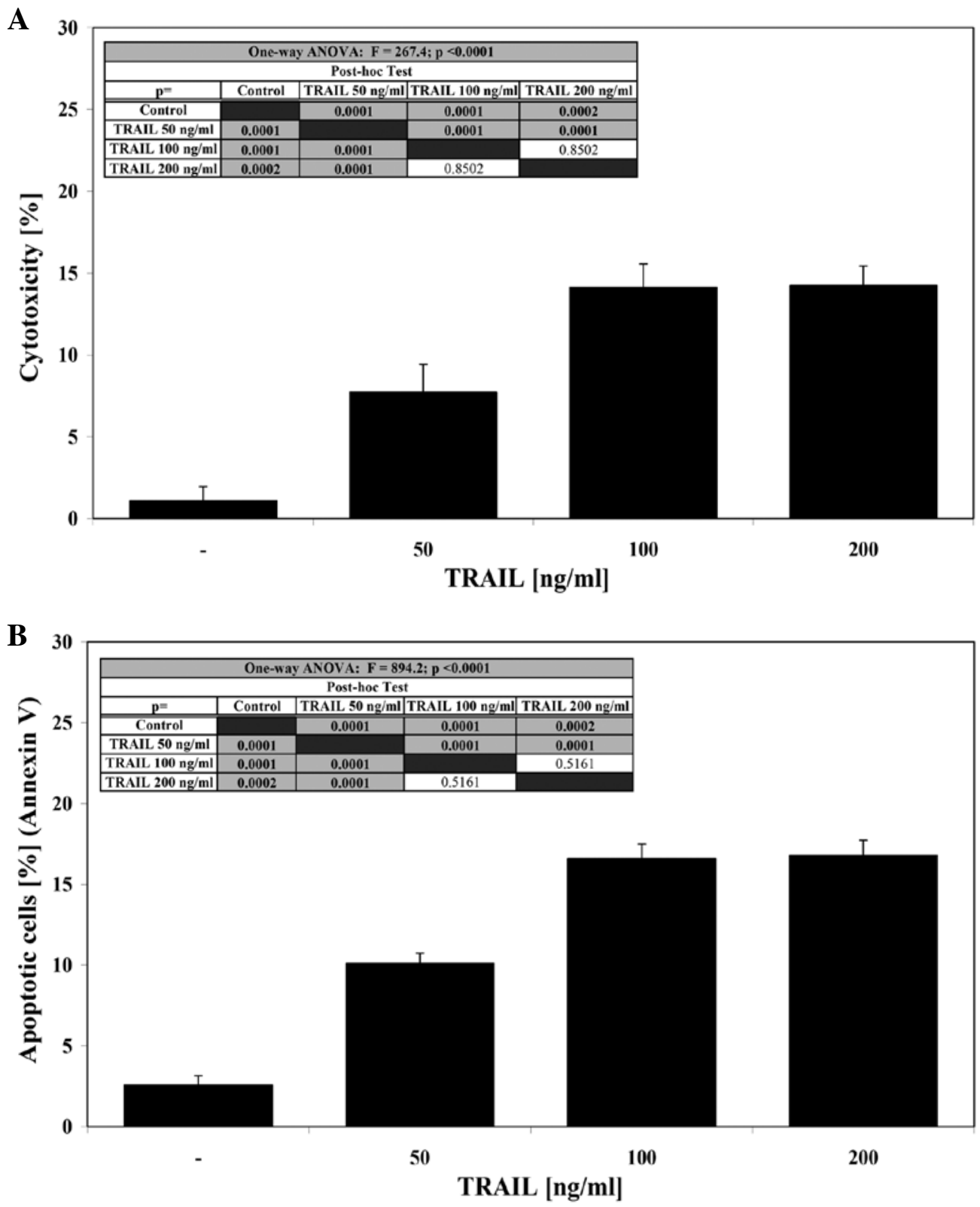

Figure 2. Cytotoxic and apoptotic effects of TRAIL on LNCaP prostate cancer cells. Cells were incubated for $24 \mathrm{~h}$ with 50-200 ng/ml TRAIL. (A) Cytotoxic activity of TRAIL in LNCaP cells. The percentage of cell death was measured using the MTT cytotoxicity assay. The values represent the means \pm SD of three independent experiments performed in quadruplicate, $\mathrm{n}=12$ ( $\mathrm{p}<0.0001$ as shown by ANOVA). (B) TRAIL-induced apoptosis in LNCaP cells. Apoptotic cell death was detected by flow cytometry using Annexin V-FITC staining. The values represent the means \pm SD of three independent experiments performed in duplicate, $\mathrm{n}=6(\mathrm{p}<0.0001$ as shown by ANOVA).

kit from Biotium, Inc. (Hayward, CA, USA) (15,17). LNCaP cells $\left(2 \times 10^{5} / \mathrm{ml}\right)$ were seeded in a $24-w e l l$ plate for $24 \mathrm{~h}$ before the experiments. TRAIL (100 ng/ml) and/or artepillin C (50 and $100 \mu \mathrm{M}$ ) were added to the cells, and $24 \mathrm{~h}$ later, the cells were washed with PBS and trypsinised. The cells were then centrifuged to discard the supernatant, washed with PBS and resuspended in binding buffer (100 $\mu \mathrm{l} / \mathrm{sample})$. A combination of $5 \mu \mathrm{l}$ of Annexin V-FITC, $5 \mu \mathrm{l}$ of ethidium homodimer III and $5 \mu \mathrm{l}$ of Hoechst 33342 solution was added to each tube. The samples were incubated at room temperature for $15 \mathrm{~min}$ in the dark, and then the cells were washed with binding buffer, placed on a glass slide and covered with a glass cover slip. The stained cells were observed with an IX51 fluorescence inverted microscope (Olympus, Tokyo, Japan) using filter sets for FITC,
TRITC and DAPI. The cells were counted, and the number of apoptotic cells is expressed as a percentage of the total number of cells.

Flow cytometric analysis of death receptor expression on the cell surface. The cell surface expression of the death receptors, TRAIL-R1 and TRAIL-R2, was determined by flow cytometry (BD FACSCanto, Becton-Dickinson Immunocytometry Systems). LNCaP cells $\left(2 \times 10^{5} / \mathrm{ml}\right)$ were seeded in 24-well plates for $24 \mathrm{~h}$ and exposed to artepillin $\mathrm{C}(50$ and $100 \mu \mathrm{M})$ for $24 \mathrm{~h}$. The cells were then harvested using a solution of trypsin and ethylenediaminetetraacetic acid (EDTA), washed twice in PBS and resuspended in PBS containing $0.5 \%$ bovine serum albumin (BSA). LNCaP cells were incubated with $10 \mu \mathrm{l}$ 

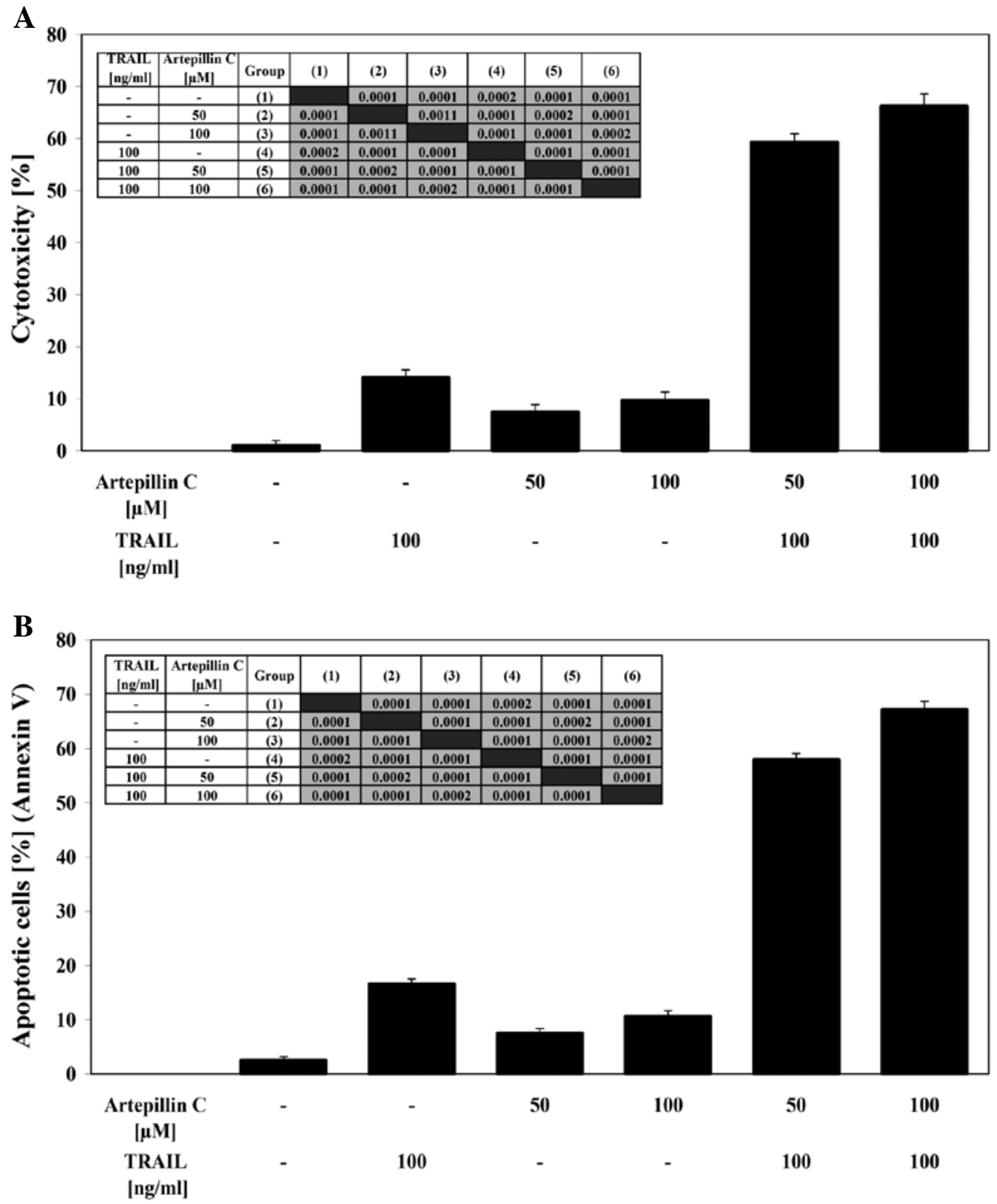

Figure 3. Cytotoxic and apoptotic effects of TRAIL in combination with artepillin C in LNCaP prostate cancer cells. Cells were incubated for $24 \mathrm{~h}$ with $100 \mathrm{ng} / \mathrm{ml}$ TRAIL and/or 50-100 $\mu \mathrm{M}$ artepillin C. (A) Cytotoxic activity of TRAIL in combination with artepillin C in LNCaP cells. The percentage of cell death was measured using the MTT cytotoxicity assay. The values represent the means \pm SD of three independent experiments performed in quadruplicate, $\mathrm{n}=12$ ( $\mathrm{p}<0.0001$ TRAIL + artepillin C compared to TRAIL or artepillin C alone as shown by ANOVA). (B) TRAIL-induced apoptosis in combination with artepillin $\mathrm{C}$ in $\mathrm{LNCaP}$ cells. Apoptotic cell death was detected by flow cytometry using annexin V-FITC staining. The values represent the means \pm SD of three independent experiments performed in duplicate, $\mathrm{n}=6(\mathrm{p}<0.0001$ TRAIL + artepillin C compared to TRAIL or artepillin C alone as shown by ANOVA).

phycoerythrin-conjugated anti-TRAIL-R1 or anti-TRAIL-R2 monoclonal antibody (R\&D Systems) at $4^{\circ} \mathrm{C}$ for $45 \mathrm{~min}$. After staining, the cells were washed with PBS and analyzed using flow cytometry $(17-20,50)$. The control sample consisted of cells in a separate tube treated with phycoerythrin-labelled mouse $\mathrm{IgG}_{1}$ or mouse $\mathrm{IgG}_{2 \mathrm{~B}}$ (R\&D Systems).

Caspase activity assays. Caspase- 3 and caspase- 8 activities were assessed using colorimetric protease assay kits (R\&D Systems). The tests are based on the spectrophotometric detection of the chromophore, $p$-nitroaniline (pNA), after cleavage from the caspase substrate (caspase-specific peptide conjugated to pNA). $\mathrm{LNCaP}$ cells $\left(1 \times 10^{6} / \mathrm{ml}\right)$ were seeded in Petri dishes
$24 \mathrm{~h}$ before the experiments. TRAIL (100 $\mathrm{ng} / \mathrm{ml})$ and/or artepillin $\mathrm{C}(50-100 \mu \mathrm{M})$ were added to the cells, after $24 \mathrm{~h}$ the cells were centrifuged, the supernatant was discarded and the cells were treated with lysis buffer. The cell lysates were tested for protease activity by the addition of a labelled caspase substrate, DEVD-pNA for caspase-3 activity or IETD-pNA for caspase-8 activity. pNA absorbance was quantified using a V-630 spectrophotometer (Jasko International Co., Tokyo, Japan) at a 405-nm wavelength (20).

Evaluation of $\Delta \Psi m$ by DePsipher staining. The DePsipher kit (R\&D Systems) was used to measure the $\Delta \Psi \mathrm{m}$ using fluorescence microscopy (17-20). LNCaP cells $\left(2 \times 10^{5} / \mathrm{ml}\right)$ 


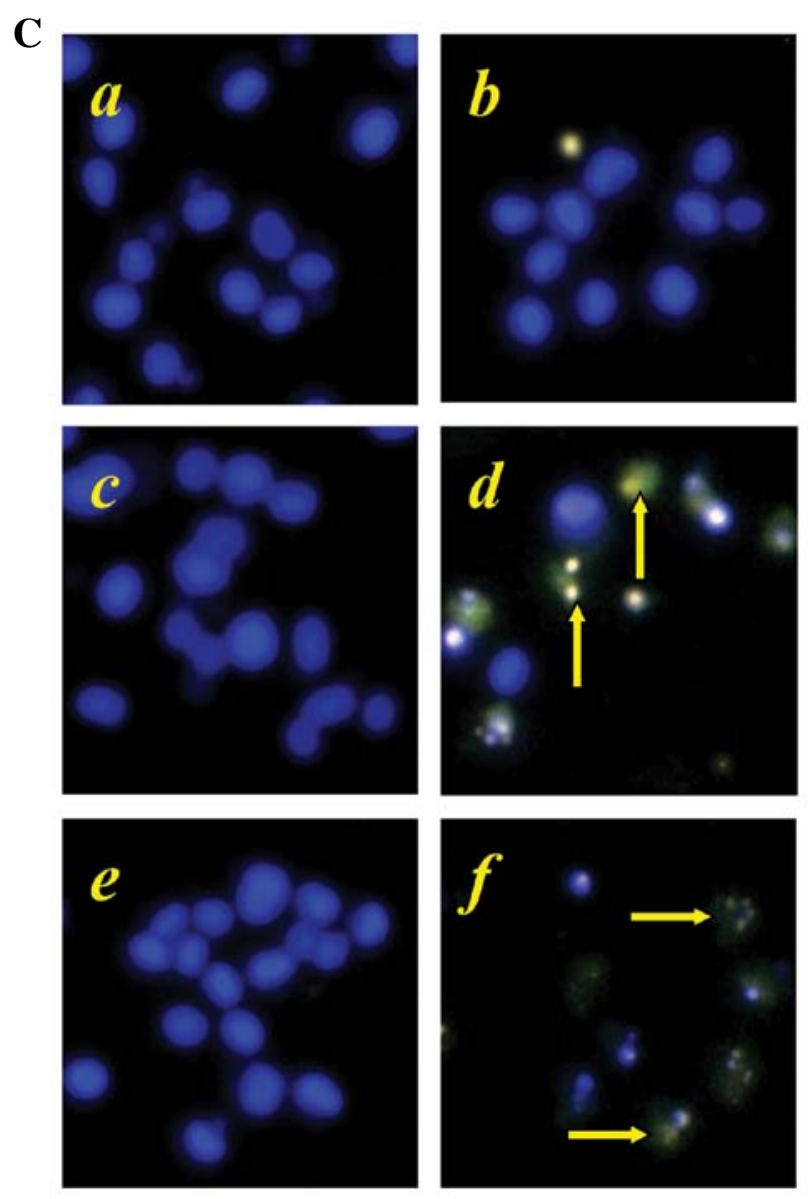

Figure 3. Continued. (C) TRAIL-induced apoptosis in combination with artepillin C in LNCaP cells: (a) control cells, (b) cells incubated with $100 \mathrm{ng} / \mathrm{ml}$ TRAIL, (c) cells incubated with $50 \mu \mathrm{M}$ artepillin C, (d) cells incubated with $100 \mathrm{ng} / \mathrm{ml}$ TRAIL and $50 \mu \mathrm{M}$ artepillin C, (e) cells incubated with $100 \mu \mathrm{M}$ artepillin C and (f) cells incubated with $100 \mathrm{ng} / \mathrm{ml}$ TRAIL and $100 \mu \mathrm{M}$ artepillin C. Apoptotic cell death was detected and visualised by fluorescence microscopy using Annexin V-FITC staining. Healthy cells (stained with Hoechst 33342) emitted blue fluorescence and apoptotic cells (stained with Hoechst 33342 and annexin V-FITC) emitted green and blue fluorescence (indicated by arrows).

were seeded in a 24 -well plate $24 \mathrm{~h}$ prior to the experiments. TRAIL (100 ng/ml) and/or artepillin C (50-100 $\mu \mathrm{M})$ were added, and $24 \mathrm{~h}$ later, the cells were washed with PBS and harvested by trypsinisation. The cells were incubated in the dark with DePsipher (5,5',6,6'-tetrachloro-1,1',3,3'-tetraethylbenzimidazolyl carbocyanin iodide) solution at a concentration of $5 \mu \mathrm{g} / \mathrm{ml}$ for $30 \mathrm{~min}$ at $37^{\circ} \mathrm{C}$, washed with reaction buffer with stabiliser, placed on a glass slide and covered with a glass cover slip. The stained cells were observed with a fluorescence inverted microscope using filter sets for FITC and TRITC. DePsipher staining exhibits potential-dependent accumulation in the mitochondria, which is indicated by a fluorescence emission shift from red $(590 \mathrm{~nm})$ to green $(530 \mathrm{~nm})$.

The activity of $N F-\kappa B$. NF- $\kappa \mathrm{B}$ activity was measured using the ELISA-based TransAM NF- $\kappa \mathrm{B}$ kit (Active Motif Europe, Rixensart, Belgium) on nuclear extracts. LNCaP cells $\left(1 \times 10^{6} / \mathrm{ml}\right)$ were seeded in Petri dishes and allowed to attach for $24 \mathrm{~h}$ before the experiments. Artepillin C (50-100 $\mu \mathrm{M})$ with or without TRAIL $(100 \mathrm{ng} / \mathrm{ml})$ was added to the cells for $24 \mathrm{~h}$.
The commercially available Nuclear Extract kit was obtained from Active Motif Europe for the preparation of the LNCaP cell nuclear extracts. The TransAM NF-assay for $\mathrm{NF}-\kappa \mathrm{B}$ (p65) activity was performed according to the manufacturer's instructions $(17,19,20)$. NF- $\kappa$ B DNA-binding activity was assessed using the ELISA kit for the transcription factor, p65. Oligonucleotides containing the $\mathrm{NF}-\kappa \mathrm{B}$ consensus binding site (5'-GGGACTTCC-3') were immobilised on a 96-well plate. The active forms of $\mathrm{NF}-\kappa \mathrm{B}$ in the nuclear extracts were bound to the oligonucleotides on the plate and detected colorimetrically. The samples were read at an absorbance of $450 \mathrm{~nm}$ on a spectrophotometer with a reference wavelength of $650 \mathrm{~nm}$. The detection limit for the TransAM NF- $\mathrm{B}$ kit is $<0.4 \mathrm{ng} / \mathrm{ml}$ purified $\mathrm{p} 65$

Statistical analysis. The results are expressed as the means \pm SD obtained from three independent experiments performed in quadruplicate $(n=12)$ or duplicate $(n=6)$. Statistical significance was evaluated using the Levene test or Bartlett $\chi^{2}$ test followed by analysis of variance (ANOVA) and post-hoc test. A p-value $<0.05$ was considered significant.

\section{Results}

Cytotoxic and apoptotic effects of TRAIL on LNCAP cells. The cytotoxic effect of TRAIL at concentrations of 50-100 ng/ml after a $24-\mathrm{h}$ incubation was $7.7 \pm 1.7-14.1 \pm 1.4 \%$ cell death (Fig. 2A). At the same concentrations TRAIL induced 10.1 \pm 0.6 $16.6 \pm 0.9 \%$ apoptosis in a dose-dependent manner in $\mathrm{LNCaP}$ cells (Fig. 2B). TRAIL concentrations higher than $100 \mathrm{ng} / \mathrm{ml}$ resulted in no significant increase in cytotoxic or apoptotic activity. These data confirm that the LNCaP cell line is resistant to TRAIL-mediated apoptosis.

Cytotoxic and apoptotic effects of TRAIL in combination with artepillin C on LNCaP cells. After co-treatment of LNCaP cells with $100 \mathrm{ng} / \mathrm{ml}$ TRAIL and 50-100 $\mu \mathrm{M}$ artepillin $\mathrm{C}$ for $24 \mathrm{~h}$ the cytotoxicity ranged from $59.3 \pm 1.6$ to $66.3 \pm 2.3 \%$. The cyto toxicity measured by MTT assay is shown in Fig. 3A. Artepillin C cooperated with TRAIL to induce apoptosis in the prostate cancer cells. When the cells were treated with the same concentration of TRAIL and artepillin C for $24 \mathrm{~h}$, the percentage of apoptotic cells was elevated to $58.0 \pm 1.1-67.2 \pm 1.5 \%$ as determined by Annexin V-FITC staining using flow cytometry (Fig. 3B). Artepillin C sensitized the TRAIL-resistant LNCaP cells to TRAIL-mediated apoptosis. The necrotic cell death percentage of LNCaP cells examined by Apoptest-FITC and LDH assay was near zero. The Annexin V-FITC staining, visualised by fluorescence microscopy, supports the hypothesis that the apoptotic activity of TRAIL was augmented by artepillin C in LNCaP cells (Fig. 3C).

Effects of artepillin $C$ on death receptor expression in LNCaP cells. The activation of death receptors on the cell surface is critical for TRAIL-mediated apoptosis. Therefore, we analyzed the expression of TRAIL-R1 and TRAIL-R2 in LNCaP cells after a $24-\mathrm{h}$ treatment with $50-100 \mu \mathrm{M}$ artepillin $\mathrm{C}$ by flow cytometry (Fig. 4). Treatment with artepillin $\mathrm{C}$ significantly increased the expression of TRAIL-R2, but did not alter TRAIL-R1 expression on the cell surface. Artepillin C sensitized the prostate cancer cells through the extrinsic apoptotic 
A
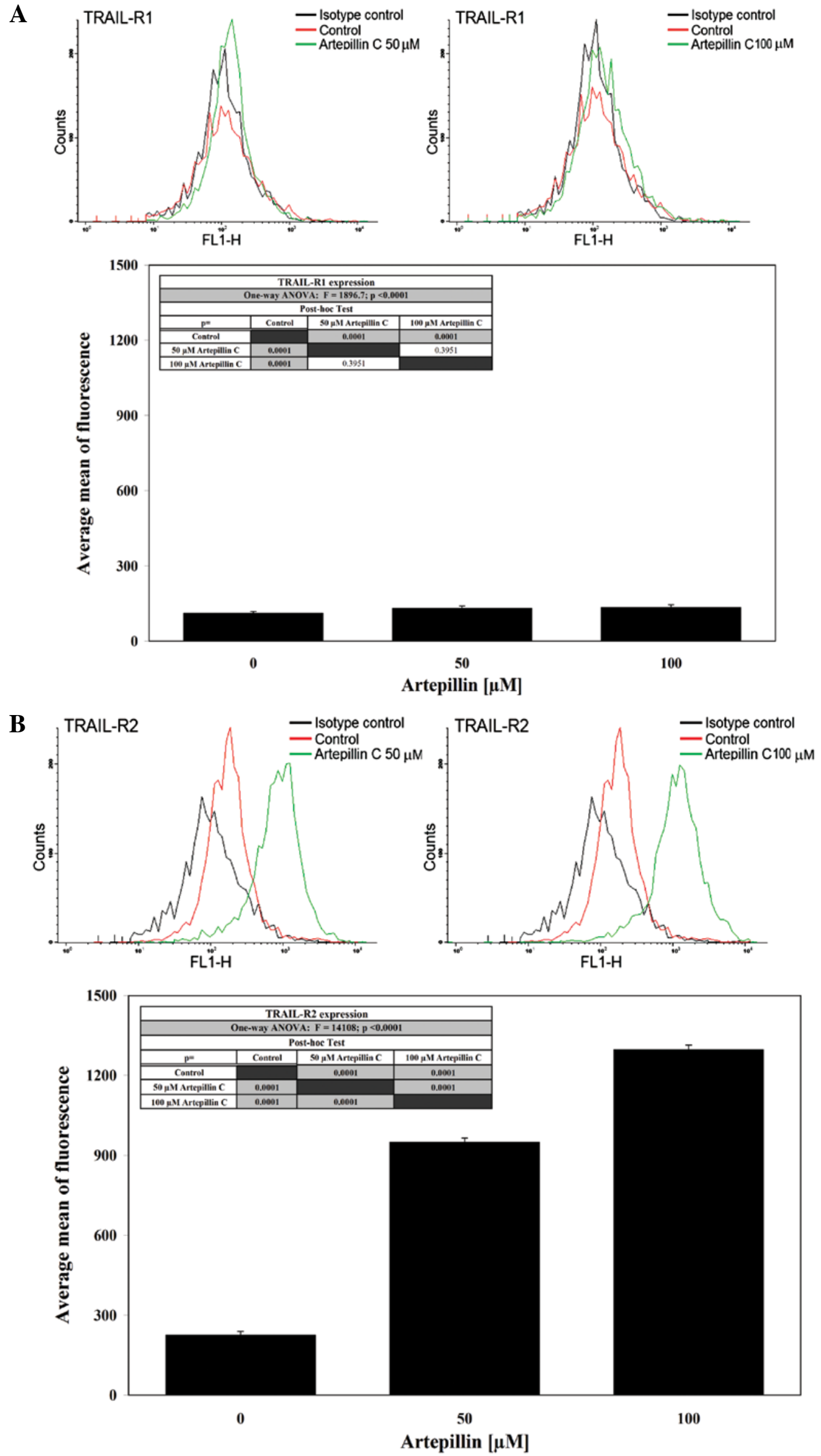

Figure 4. Effects of artepillin $\mathrm{C}$ on death receptor expression in LNCaP prostate cancer cells. Cells were incubated for $24 \mathrm{~h}$ with $50-100 \mu \mathrm{M}$ artepillin $\mathrm{C}$. The surface expression of TRAIL-R1 and TRAIL-R2 on LNCaP cells was measured by flow cytometry. Representative histograms and the average mean fluorescence for (A) TRAIL-R1 expression and for (B) TRAIL-R2 expression are shown from three independent experiments performed in duplicate, $\mathrm{n}=6$. The values represent the means $\pm \mathrm{SD}(\mathrm{p}<0.0001$ artepillin $\mathrm{C}$ compared to control as shown by ANOVA). 

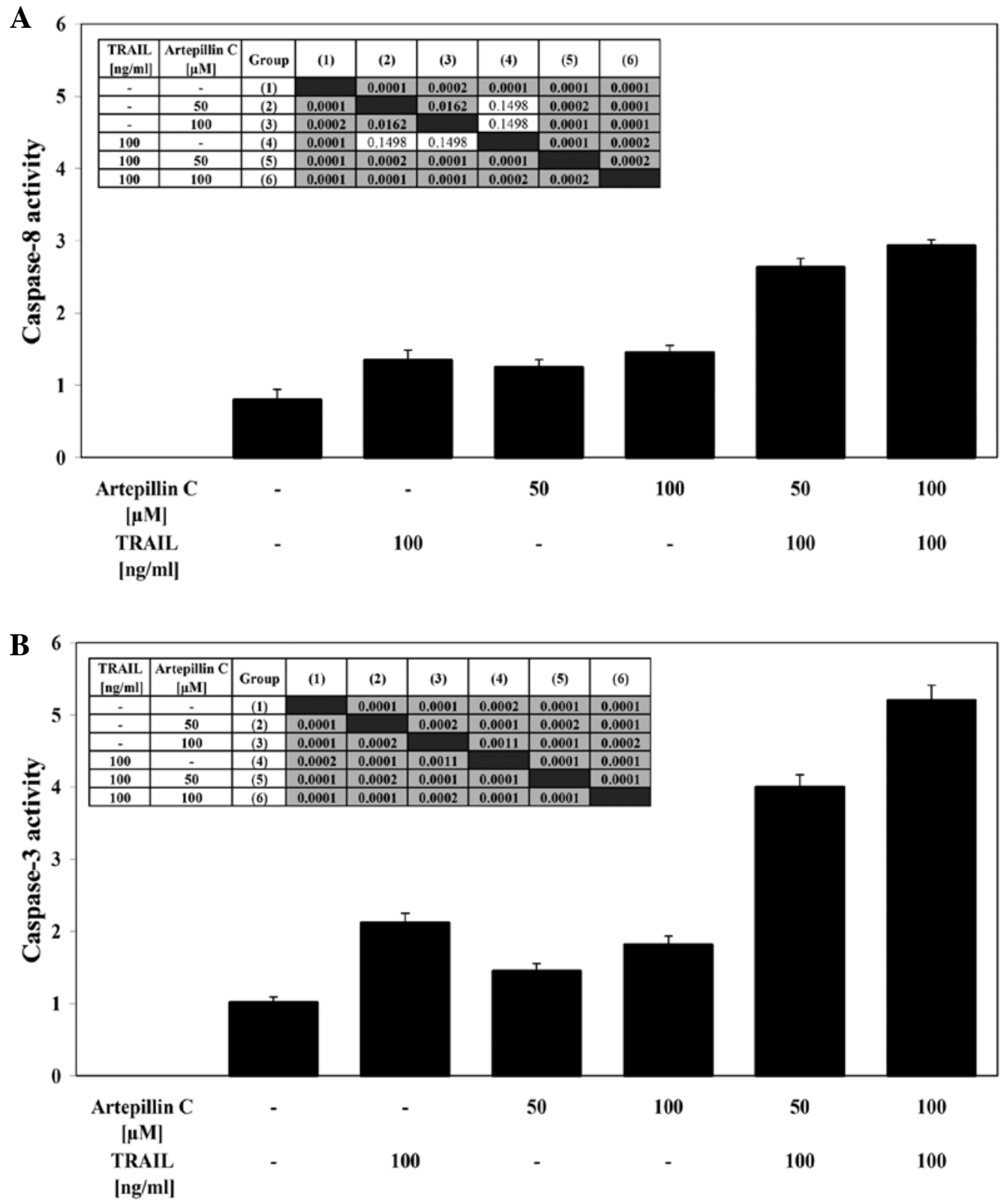

Figure 5. Effects of TRAIL in combination with artepillin $\mathrm{C}$ on caspase activities in LNCaP prostate cancer cells. Assessment of intracellular (A) caspase-8 and (B) caspase-3 activity in cells treated with $100 \mathrm{ng} / \mathrm{ml}$ TRAIL and/or 50-100 $\mu \mathrm{M}$ artepillin C for $24 \mathrm{~h}$. Caspase activities were measured using colorimetric protease assays based on the spectrophotometric detection of the chromophore, $p$-nitroaniline ( $\mathrm{pNa}$ ), after its cleavage from the labelled caspase substrates. The values represent the means \pm SD of three independent experiments performed in duplicate, $n=6(p<0.0001$ TRAIL + artepillin C compared to TRAIL or artepillin $\mathrm{C}$ alone as shown by ANOVA).

pathway. To show that the induction of apoptosis caused by the co-treatment of TRAIL and artepillin $\mathrm{C}$ was mediated through TRAIL-R2, we used the TRAIL-R2/Fc chimera protein, which acts as a dominant-negative against endogenous TRAIL-R2. The chimeric protein efficiently blocked apoptosis when the cells were treated with TRAIL and artepillin C.

Effects of TRAIL and artepillin C on caspase-8 and caspase-3 activities in LNCaP cells. LNCaP cells were treated with $100 \mathrm{ng} / \mathrm{ml}$ TRAIL and/or 50-100 $\mu \mathrm{M}$ artepillin $\mathrm{C}$ for the indicated period of time. The stimulation of death receptors induces DISC formation, resulting in the recruitment and activation of caspase-8. TRAIL and artepillin C alone weakly activated caspase- 8 in cancer cells. The simultaneous incubation of LNCaP cells with TRAIL and artepillin C significantly increased the caspase- 8 activity (Fig. 5A). Caspase- 3 is an effector caspase that plays a central role in apoptosis. Co-treatment of LNCaP cells with TRAIL and artepillin C markedly enhanced caspase- 3 activity compared to treatment with TRAIL or artepillin C alone (Fig. 5B). The use of the pan-caspase inhibitor, Z-VAD-FMK, the caspase- 8 inhibitor, Z-IETD-FMK, or the caspase-3 inhibitor, Z-DEVD-FMK, completely blocked the subsequent cell death induced by TRAIL in combination with artepillin C. These results suggest that artepillin $\mathrm{C}$ promotes TRAIL-mediated apoptosis through a caspase cascade. 


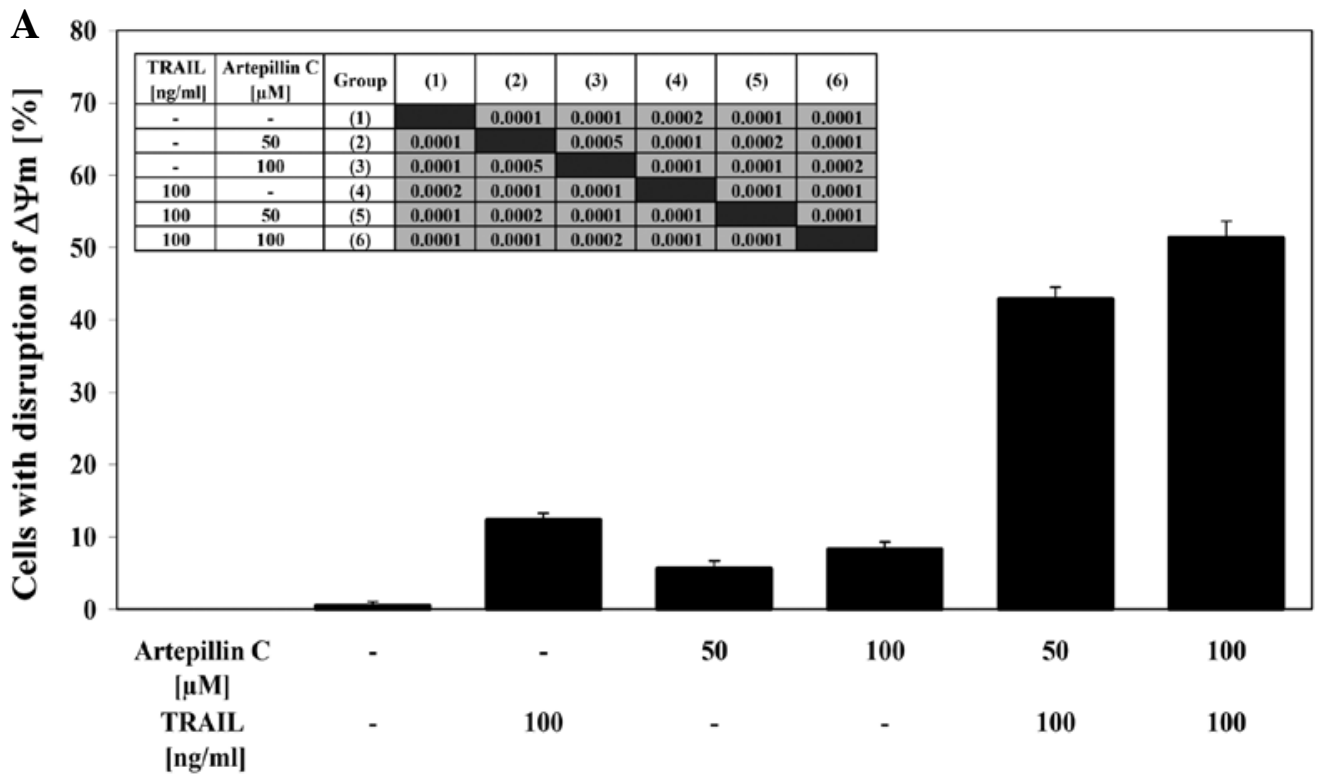

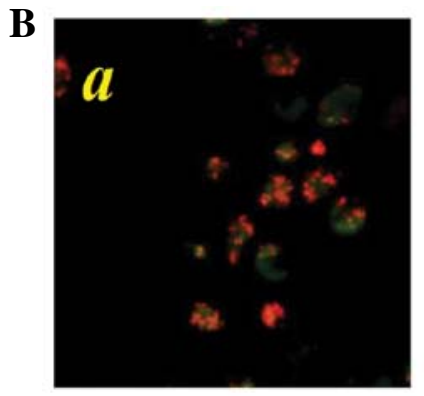
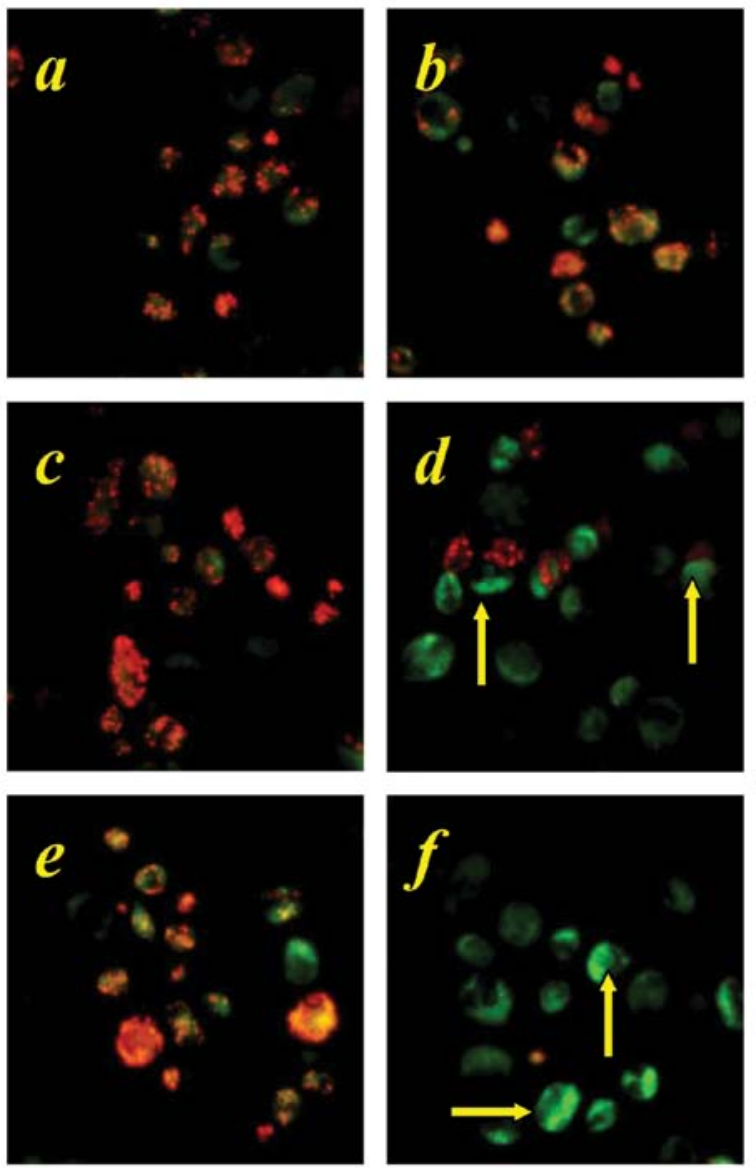

Figure 6. Effects of TRAIL in combination with artepillin $\mathrm{C}$ on the mitochondrial membrane potential $(\Delta \Psi \mathrm{m})$ in LNCaP prostate cancer cells. Cells were incubated for $24 \mathrm{~h}$ with $100 \mathrm{ng} / \mathrm{ml}$ TRAIL and/or 50-100 $\mu \mathrm{M}$ artepillin C. The values represent the meana $\pm \mathrm{SD}$ of three independent experiments performed in duplicate, $\mathrm{n}=6$ ( $\mathrm{p}<0.001$ TRAIL + artepillin C compared to TRAIL or artepillin $\mathrm{C}$ alone as shown by ANOVA). (A) TRAIL in combination with artepillin $\mathrm{C}$ induced a loss of $\Delta \Psi \mathrm{m}$ in LNCaP cells. (B) Disruption of $\Delta \Psi \mathrm{m}$ in LNCaP cells was assessed by fluorescent microscopic analysis of DePsipher staining using the following treatment conditions: (a) control cells, (b) cells incubated with $100 \mathrm{ng}$ ml TRAIL, (c) cells incubated with $50 \mu \mathrm{M}$ artepillin C, (d) cells incubated with $100 \mathrm{ng} / \mathrm{ml}$ TRAIL and $50 \mu \mathrm{M}$ artepillin C, (e) incubated with $100 \mu \mathrm{M}$ artepillin $\mathrm{C}$ and (f) cells incubated with $100 \mathrm{ng} / \mathrm{ml}$ TRAIL and $100 \mu \mathrm{M}$ artepillin C. Red fluorescence is emitted from aggregates of DePsipher, which are formed within the mitochondria of healthy cells. Green fluorescence reveals the monomeric form of the DePsipher molecule, which appears in the cytosol after mitochondrial membrane depolarisation (indicated by arrows).
Effects of TRAIL and artepillin C on $\triangle \Psi m$ in LNCaP cells. Mitochondrial membrane depolarization is one of the first intracellular changes that occur after the onset of apoptosis. We evaluated whether artepillin $\mathrm{C}$ sensitizes cancer cells to TRAIL-induced mitochondrial dysfunction. When the LNCaP cells were treated with $100 \mathrm{ng} / \mathrm{ml}$ TRAIL or $50-100 \mu \mathrm{M}$ artepillin $\mathrm{C}$ alone, there was little effect on $\Delta \Psi \mathrm{m}(12.4 \pm 0.9 \%$ and 5.6 $\pm 1.1-8.3 \pm 1.0 \%$, respectively). The combination treatment of TRAIL with artepillin C enhanced the loss of $\Delta \Psi \mathrm{m}$ in a large percentage of the cells $(42.9 \pm 1.6-51.4 \pm 2.3 \%)$ and induced a significant disruption of the $\Delta \Psi \mathrm{m}$ (Fig. 6A and B). These results demonstrate that the intrinsic apoptotic pathway is engaged in LNCaP cells treated with both TRAIL and artepillin C.

Effects of artepillin $C$ and TRAIL on NF- $\kappa B$ activity in LNCaP cells. We examined the effect of artepillin $C$ and/or TRAIL on NF- $\kappa \mathrm{B}$ activation in LNCaP cells (Fig. 7). Using the ELISAbased TransAM NF- $\kappa B$ test, we determined the binding activity of the p65 subunit in $\mathrm{LNCaP}$ nuclear extracts. Treatment with artepillin $\mathrm{C}$ decreased the activity of NF- $\mathrm{KB}$ compared with the control cells. By contrast, TRAIL induced the activation of NF- $\mathrm{KB}$ in the LNCaP cells. The co-treatment of artepillin C with TRAIL also significantly decreased the NF- $\kappa \mathrm{B}$ activity. This shows that artepillin $\mathrm{C}$ can help cells overcome TRAIL resistance in $\mathrm{LNCaP}$ cells by blocking the NF- $\kappa \mathrm{B}$ activation induced by TRAIL.

\section{Discussion}

Propolis contains various phenolic compounds and exhibits a broad spectrum of biological activities $(16,36,47)$. The composition of propolis is complex and largely depends on the geographical origin and specific flora at the site of its collection (17,47). Baccharis dracunculiforia is the main botanical source of resins for the green propolis rich in artepillin C (21-23). Phenolic ingredients contribute to the overall cancer preventive and antitumour effects of propolis $(16,36)$. Therefore, propolis 


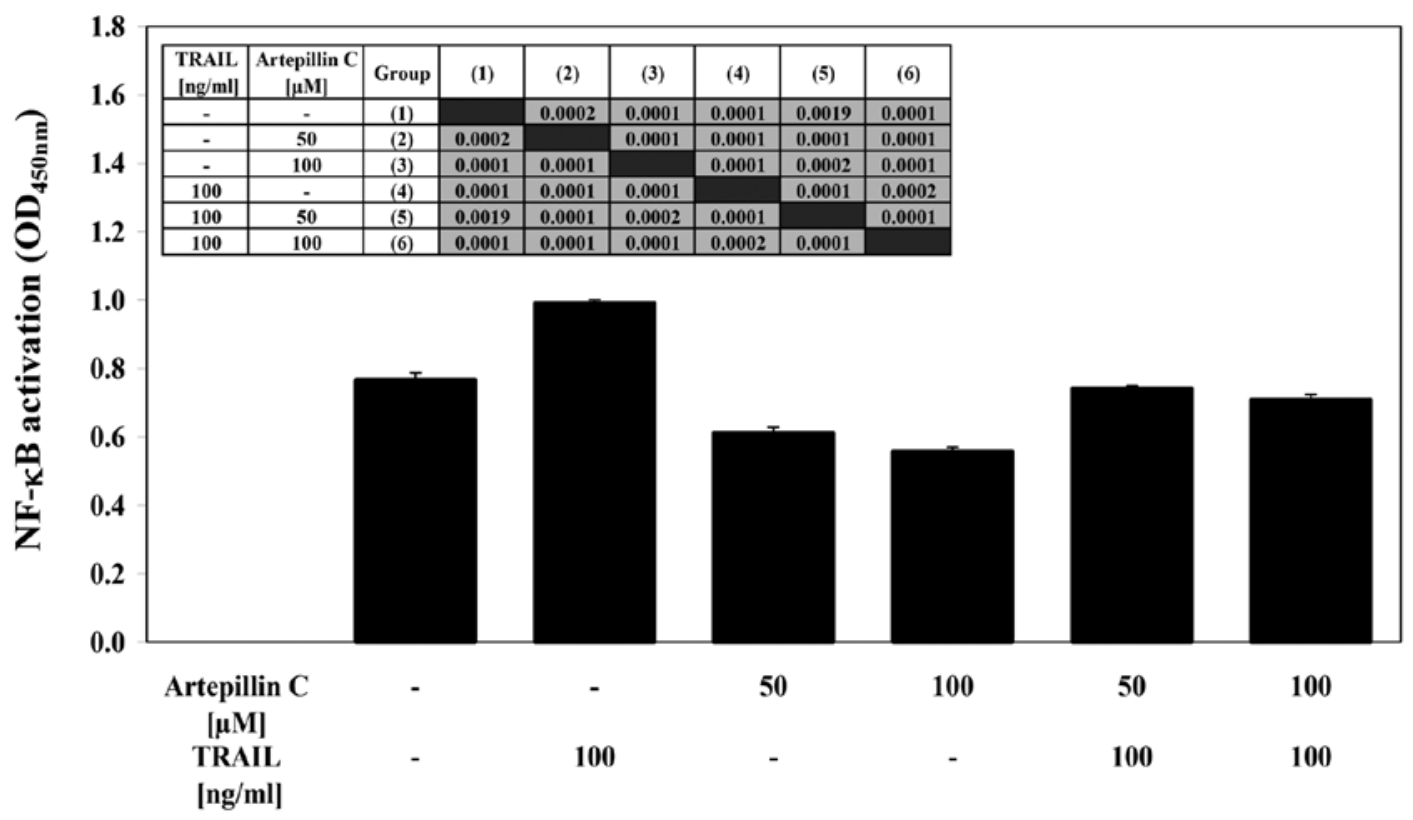

Figure 7. Effects of artepillin C and TRAIL on NF- $\kappa \mathrm{B}$ activity in LNCaP prostate cancer cells. Cells were incubated for $24 \mathrm{~h}$ with $50-100 \mu \mathrm{M}$ artepillin $\mathrm{C}$ and/ or $100 \mathrm{ng} / \mathrm{ml}$ TRAIL. The values represent the means \pm SD of three independent experiments performed in duplicate, $\mathrm{n}=6$ ( $\mathrm{p}<0.0001 \mathrm{TRAIL}+\mathrm{artepillin} \mathrm{C}$ compared to TRAIL or artepillin $\mathrm{C}$ alone as shown by ANOVA). The effects of artepillin $\mathrm{C}$ and/or TRAIL on the NF- $\mathrm{B}$ (p65) binding activity in LNCaP nuclear extracts were measured using the ELISA-based TransAM NF- $\kappa$ B assay.

is a promising raw mixture of natural compounds that should be studied to discover new pharmaceutical products with chemopreventive properties.

Artepillin $\mathrm{C}$ has shown a marked activity against different tumour cells in vitro, and it affects cancer cells by inhibiting cell growth and inducing apoptosis (24-26). Akao et al demonstrated the suppression of tumour cell growth by artepillin $\mathrm{C}$ and two other cinnamic acid derivatives detected in propolis, drupanin and baccharin (51). In our study, artepillin C exerted low direct cytotoxic and apoptotic effects on LNCaP cells. Numerous tests have confirmed that the LNCaP prostate cancer cell line is resistant to TRAIL-mediated apoptosis (15-20). Inactivation of the TRAIL pathway and escape from the TRAIL-mediated immunosurveillance may play important roles in tumour onset and progression (2). Previous studies have shown that TRAIL in combination with propolis extracts or phenolic compounds identified in propolis results in the synergistic induction of cancer cell death $(16,17,47)$. We then treated the TRAIL-resistant LNCaP cells with a combination of TRAIL and artepillin C. The tested compound significantly augmented TRAIL-induced death in the prostate cancer cells. These results suggest that artepillin $\mathrm{C}$ exhibits mainly indirect antitumour action by stimulating the TRAIL-mediated apoptotic pathway.

TRAIL triggers a pro-apoptotic signal by binding to the death receptors. The inactivation of TRAIL-R2 (also known as DR5) significantly increases tumour growth in vitro and in vivo. Thus, the expression of TRAIL-R2 may contribute to the tumour selective induction of apoptosis mediated by TRAIL (1-5). We found that the artepillin C-mediated sensitization of LNCaP cells to TRAIL-induced apoptosis is associated with the upregulation of TRAIL-R2 expression. Indeed, other phenolic compounds isolated from propolis can evoke similar increases in the cell surface expression of TRAIL-R2. Apigenin, kaempferol and quercetin, all reverse TRAIL resistance in cancer cells by influencing TRAIL-R2 levels $(12,13,52)$.

Caspases are crucial players in the induction of apoptosis. TRAIL-mediated apoptosis is primarily executed by the extrinsic death receptor pathway. This pathway involves caspase- 8 as the initiator and caspase- 3 as the executor $(2,19)$. We observed that co-treatment with TRAIL and artepillin C resulted in the significant activation of caspase- 8 and caspase- 3 in LNCaP cells, whereas treatment with TRAIL or artepillin C alone weakly activated both caspases. Previous studies have reported that TRAIL induces caspase cleavage when combined with propolis constituents (apigenin, chrysin, kaempferol and quercetin) in cancer cells $(12,13,52,53)$. The present study confirms that the sensitization of prostate cancer cells to TRAIL by artepillin $\mathrm{C}$ is accomplished through an extrinsic, receptorand caspase-dependent pathway.

Mitochondrial dysfunction is considered a hallmark of apoptosis $(14,18,19)$. Further analysis of the $\Delta \Psi \mathrm{m}$ showed that the TRAIL and artepillin $\mathrm{C}$ co-treatment affected the intrinsic pathway in LNCaP cells via a significant reduction in $\Delta \Psi \mathrm{m}$ compared to treatment with TRAIL or artepillin $\mathrm{C}$ alone.

In addition to defects in the extrinsic and intrinsic apoptotic pathways, the NF- $\mathrm{B}$ survival pathway in tumour cells may be responsible for the failure to undergo apoptosis $(19,20,54)$. The activation of NF- $\kappa B$ in LNCaP cells leads to TRAIL resistance, while the downregulation of $\mathrm{NF}-\kappa \mathrm{B}$ by artepillin $\mathrm{C}$ sensitizes cancer cells to TRAIL-mediated death.

To our knowledge, in this study, we show for the first time the mechanisms by which artepillin $C$ helps cancer cells to overcome TRAIL resistance. Artepillin $\mathrm{C}$ achieves this through the upregulation of the TRAIL-R2 receptor, activation of caspase- 8 and caspase-3, the loss of $\Delta \Psi \mathrm{m}$ and the downregulation of 
$\mathrm{NF}-\kappa \mathrm{B}$. Artepillin $\mathrm{C}$ as the main phenolic compound isolated from Brazilian green propolis sensitizes prostate cancer cells to TRAIL-induced apoptosis, engaging similar cellular targets in LNCaP cells, such as those induced by EEP (17). The evidence confirms that of all the phenolic compounds in Brazilian green propolis, artepillin $\mathrm{C}$ is predominantly responsible for the action of propolis on TRAIL-mediated apoptosis in cancer cells.

These results define the cancer chemopreventive action of artepillin $\mathrm{C}$ through the modulation of TRAIL-mediated apoptotic signalling pathways. We hypothesize that artepillin $\mathrm{C}$ supports TRAIL-mediated immune defense against cancer cells and may therefore represent a prostate cancer immunochemopreventive agent.

\section{Acknowledgements}

This project was supported by a research grant (KNW-1017/P/1/0) from the Medical University of Silesia in Katowice (Poland).

\section{References}

1. Lee JY, Huerta-Yepez S, Vega M, Baritaki S, Spandidos DA and Bonavida B: The NO TRAIL to YES TRAIL in cancer therapy (Review). Int J Oncol 31: 685-691, 2007.

2. Voelkel-Johnson C: TRAIL-mediated signaling in prostate, bladder and renal cancer. Nat Rev Urol 8: 417-427, 2011.

3. Baritaki S, Katsman A, Chatterjee D, Yeung KC, Spandidos DA and Bonavida B: Regulation of tumor cell sensitivity to TRAILinduced apoptosis by the metastatic suppressor Raf kinase inhibitor protein via Yin Yang 1 inhibition and death receptor 5 up-regulation. J Immunol 179: 5441-5453, 2007.

4. Baritaki S, Huerta-Yepez S, Sakai T, Spandidos DA and Bonavida B: Chemotherapeutic drugs sensitize cancer cells to TRAIL-mediated apoptosis: up-regulation of DR5 and inhibition of Yin Yang 1. Mol Cancer Ther 6: 1387-1399, 2007.

5. Baritaki S, Suzuki E, Umezawa K, Spandidos DA, Berenson J, Daniels TR, Penichet ML, Jazirehi AR, Palladino M and Bonavida B: Inhibition of Yin Yang 1-dependent repressor activity of DR5 transcription and expression by the novel proteasome inhibitor NPI-0052 contributes to its TRAIL-enhanced apoptosis in cancer cells. J Immunol 180: 6199-6210, 2008.

6. Szliszka E and Krol W: The role of dietary polyphenols in tumor necrosis factor-related apoptosis inducing ligand (TRAIL)induced apoptosis for cancer chemoprevention. Eur J Cancer Prev 20: 63-69, 2011.

7. Szliszka E, Bronikowska J, Majcher A, Miszkiewicz J and Krol W: Enhanced sensitivity of hormone-refractory prostate cancer cells to tumor necrosis factor-related apoptosis-inducing ligand (TRAIL) mediated cytotoxicity by taxanes. CEJ Urol 62: 29-34, 2009.

8. Szliszka E, Bronikowska J, Czuba ZP and Krol W: Isoflavones augment the effect of tumor necrosis factor-related apoptosisinducing ligand (TRAIL) on prostate cancer cells. CEJ Urol 63: 182-186, 2010.

9. Szliszka E, Gebka J, Bronikowska J and Krol W: Dietary flavones enhance the effect of tumor necrosis factor-related apoptosisinducing ligand (TRAIL) on bladder cancer cells. CEJ Urol 63: $138-143,2010$

10. Lee SJ, Noh HJ, Sung EG, Song IH, Kim JY, Kwon TK and Lee TJ: Berberine sensitizes TRAIL-induced apoptosis through proteasome-mediated downregulation of c-FLIP and Mcl-1 proteins. Int J Oncol 38: 485-492, 2011.

11. Fujiwara J, Sowa Y, Horinaka M, Koyama M, Wakada M, Miki T and Sakai T: The anti-obesity drug orlistat promotes sensitivity to TRAIL by two different pathways in hormone-refractory prostate cancer cells. Int J Oncol 40: 1483-1491, 2012.

12. Horinaka M, Yoshida T, Shiraishi T, Nakata S, Wakada M and Sakai T: The dietary flavonoid apigenin sensitizes malignant tumor cells to tumor necrosis factor-related apoptosis-inducing ligand. Mol Cancer Ther 5: 945-951, 2006.
13. Jung YH, Heo J, Lee YJ, Kwon TK and Kim YH: Quercetin enhances TRAIL-mediated apoptosis in prostate cancer cells via increased protein stability of death receptor 5 . Life Sci 86: 351-357, 2010.

14. Szliszka E, Czuba ZP, Mazur B, Paradysz A and Krol W: Chalcones and dihydrochalcones augment TRAIL-mediated apoptosis in prostate cancer cells. Molecules 15: 5336-5353, 2010.

15. Szliszka E, Czuba ZP, Sedek L, Paradysz A and Krol W: Enhanced TRAIL-mediated apoptosis in prostate cancer cells by the bioactive compounds neobavaisoflavone and psoralidin isolated from Psoralea corylifolia. Pharmacol Rep 63: 139-148, 2011.

16. Szliszka E, Czuba ZP, Bronikowska J, Mertas A, Paradysz A and Krol W: Ethanolic extract of propolis (EEP) augments TRAIL-induced apoptotic death in prostate cancer cells. Evid Based Complement Alternat Med 2011: 535172, 2011.

17. Szliszka E, Zydowicz G, Janoszka B, Dobosz C, KowalczykZiomek G and Krol W: Ethanolic extract of Brazilian green propolis sensitizes prostate cancer cells to TRAIL-induced apoptosis. Int J Oncol 38: 941-953, 2011.

18. Szliszka E and Krol W: Soy isoflavones augment the effect of TRAIL-mediated apoptotic death in prostate cancer cells. Oncol Rep 26: 533-541, 2011.

19. Szliszka E, Helewski KJ, Mizgala E and Krol W: The dietary flavonol fisetin enhances the apoptosis-inducing potential of TRAIL in prostate cancer cells. Int J Oncol 39: 771-779, 2011.

20. Szliszka E, Czuba ZP, Mertas A, Paradysz A and Krol W: The dietary isoflavone biochanin-A sensitizes prostate cancer cells to TRAIL-induced apoptosis. Urol Oncol http://dx.doi org/10.1016/j.urolonc.2011.01.019, 2011.

21. Park YK, Paredes-Guzman JF, Aguiar CL, Alencar SM and Fujiwara FY: Chemical constituents in Baccharis dracunculifolia as the main botanical origin of southeastern Brazilian propolis. J Agric Food Chem 52: 1100-1113, 2004.

22. Matsuda AH and de Almeida-Muradian LB: Validated method for the quantification of artepillin $\mathrm{C}$ in Brazilian propolis. Phytochem Anal 19: 179-183, 2008.

23. de Sousa JP, Leite MF, Jorge RF, Resende DO, da Silva Filho AA, Furtado NA, Soares AE, Spadaro AC, de Magalhaes PM and Bastos JK: Seasonality role on the phenolics from cultivated Baccharis dracunculifolia. Evid Based Complement Alternat Med 2011: 464289, 2011.

24. Matsuno T, Jung SK, Matsumoto Y, Saito M and Morikawa J: Preferential cytotoxicity to tumor cells of 3,5-diprenyl4-hydroxycinnamic acid (artepillin C) isolated from propolis. Anticancer Res 17: 3565-3568, 1997.

25. Kimoto T, Arai S, Kohguchi M, Aga M, Nomura Y, Micallef MJ, Kurimoto M and Mito K: Apoptosis and suppression of tumor growth by artepillin $\mathrm{C}$ extracted from Brazilian propolis. Cancer Detect Prev 22: 506-515, 1998.

26. Kimoto T, Aga M, Hino K, Koya-Miyata S, Yamamoto Y, Micallef MJ, Hanaya T, Arai S, Ikeda M and Kurimoto M: Apoptosis of human leukemia cells induced by artepillin $\mathrm{C}$, an active ingredient of Brazilian propolis. Anticancer Res 21: 221-228, 2001.

27. Ahn MR, Kunimasa K, Ohta T, Kumazawa S, Kamihira M, Kaji K, Uto Y,Hori H, Nagasawa H and Nakayama T: Suppression of tumor-induced angiogenesis by Brazilian propolis: major component artepillin $\mathrm{C}$ inhibits in vitro tube formation and endothelial cell proliferation. Cancer Lett 252: 235-243, 2007.

28. Paulino N, Abreu SR, Uto Y, Koyama D, Nagasawa H, Hori H, Dirsch VM, Vollmar AM, Scremin A and Bretz WA: Antiinflammatory effects of a bioavailable compound, Artepillin C, in Brazilian propolis. Eur J Pharmacol 587: 296-301, 2008.

29. Ahn MR, Kunimasa K, Kumazawa S, Nakayama T, Kaji K, Uto Y, Hori H, Nagasawa $\mathrm{H}$ and Ohta T: Correlation between antiangiogenic activity and antioxidant activity of various components from propolis. Mol Nutr Food Res 53: 643-651, 2009.

30. Izuta $H$, Narahara $Y$, Shimazawa M, Mishima S, Kondo $S$ and Hara H: 1,1-diphenyl-2-picrylhydrazyl radical scavenging activity of bee products and their constituents determined by ESR. Biol Pharm Bull 32: 1947-1951, 2009.

31. Messerli SM, Ahn MR, Kunimasa K, Yanagihara M, Tatefuji T, Hashimoto K, Mautner V, Uto Y, Hori H, Kumazawa S, Kaji K, Ohta T and Maruta H: Artepillin C (ARC) in Brazilian green propolis selectively blocks oncogenic PAK1 signaling and suppresses the growth of NF tumors in mice. Phytother Res 23: 423-427, 2009. 
32. Simoes-Ambrosio LM, Gregorio LE, Sousa JP, FigueiredoRinhel AS, Azzolini AE, Bastos JK and Lucisano-Valim YM: The role of seasonality on the inhibitory effect of Brazilian green propolis on the oxidative metabolism of neutrophils. Fitoterapia 81: 1102-1108, 2010.

33. de Azevedo Bentes Monteiro Neto M, de Souza Lima IM, Furtado RA, Bastos JK, da Silva Filho AA and Tavares DC: Antigenotoxicity of artepillin $\mathrm{C}$ in vivo evaluated by the micronucleus and comet assays. J Appl Toxicol 31: 714-719, 2011.

34. Fonseca YM, Marquele-Oliveira F, Vicentini FT, Furtado NA, Sousa JP, Lucisano-Valim YM and Fonseca MJ: Evaluation of the potential of Brazilian propolis against UV-induced oxidative stress. Evid Based Complement Alternat Med 2011: 863917, 2010.

35. Moura SA, Negri G, Salatino A, Lima LD, Dourado LP, Mendes JB, Andrade SP, Ferreira MA and Cara DC: Aqueous extract of Brazilian green propolis: primary components, evaluation of inflammation and wound healing by using subcutaneous implanted sponges. Evid Based Complement Alternat Med 2011: 748283, 2011.

36. Watanabe MA, Amarante MK, Conti BJ and Sforcin JM: Cytotoxic constituents of propolis inducing anticancer effects: a review. J Pharm Pharmacol 63: 1378-1386, 2011.

37. Androutsopoulos VP, Ruparelia K, Arroo RR, Tsatsakis AM and Spandidos DA: CYP1-mediated antiproliferative activity of dietary flavonoids in MDA-MB-468 breast cancer cells. Toxicology 264: 162-170, 2009.

38. Androutsopoulos VP, Papakyriakou A, Vourloumis D, Tsatsakis AM and Spandidos DA: Dietary flavonoids in cancer therapy and prevention: substrates and inhibitors of cytochrome P450 CYP1 enzymes. Pharmacol Ther 126: 9-20, 2010.

39. Androutsopoulos VP, Papakyriakou A, Vourloumis D and Spandidos DA: Comparative CYP1A1 and CYP1B1 substrate and inhibitor profile of dietary flavonoids. Bioorg Med Chem 19 2842-2849, 2011

40. Davalli P, Rizzi F, Caldara GF, Davoli S, Corti A, Silva A, Astancolle S, Vitale M, Bettuzzi S, Arcari M and Azzali G: Chronic administration of green tea extract to TRAMP mice induces the collapse of Golgi apparatus in prostate secretory cells and results in alterations of protein post-translational processing. Int J Oncol 39: 1521-1527, 2011.

41. Onoda C, Kuribayashi K, Nirasawa S, Tsuji N, Tanaka M, Kobayashi D, Watanabe N: (-)-Epigallocatechin-3-gallate induces apoptosis in gastric cancer cell lines by down-regulating survivin expression. Int J Oncol 38: 1403-1408, 2011.

42. Teiten MH, Gaascht F, Cronauer M, Henry E, Dicato M and Diederich M: Anti-proliferative potential of curcumin in androgen-dependent prostate cancer cells occurs through modulation of the Wingless signaling pathway. Int J Oncol 38: 603-611, 2011.
43. Miki H, Uehara N, Kimura A, Sasaki T, Yuri T, Yoshizawa K and Tsubura A: Resveratrol induces apoptosis via ROS-triggered autophagy in human colon cancer cells. Int J Oncol 40: 1020-1028, 2012.

44. Marech I, Vacca A, Ranieri G, Gnoni A and Dammacco F: Novel strategies in the treatment of castration-resistant prostate cancer (Review). Int J Oncol 40: 1313-1320, 2012.

45. Venkateswaran V and Klotz LH: Diet and prostate cancer: mechanisms of action and implications for chemoprevention. Nat Rev Urol 7: 442-453, 2010.

46. Bronikowska J, Szliszka E, Czuba ZP, Zwolinski D, Szmydki B and Krol W: The combination of TRAIL and isoflavones enhances apoptosis in cancer cells. Molecules 15: 2000-2015, 2010.

47. Szliszka E, Czuba ZP, Domino M, Mazur B, Zydowicz G and Krol W: Ethanolic extract of propolis (EEP) enhances the apoptosis-inducing potential of TRAIL in cancer cells. Molecules 14: 738-754, 2009.

48. Szliszka E, Skaba D, Czuba ZP and Krol W: Inhibition of inflammatory mediators by neobavaisoflavone in activated RAW264.7 macrophages. Molecules 16: 3701-3712, 2011.

49. Szliszka E, Czuba ZP, Kawczyk-Krupka A, Sieron-Stoltny A, Sieron A and Krol W: Chlorin-based photodynamic therapy enhances the effect of tumor necrosis factor-related apoptosisinducing ligand (TRAIL) in bladder cancer cells. Med Sci Monit 18: BR47-BR53, 2012.

50. Szliszka E, Mazur B, Zydowicz G, Czuba ZP and Krol W: TRAIL-induced apoptosis and expression of death receptor TRAIL-R1 and TRAIL-R2 in bladder cancer cells. Folia Histochem Cytobiol 47: 579-585, 2009.

51. Akao Y, Maruyama H, Matsumoto K, Ohguchi K, Nishizawa K, Sakamoto T, Araki Y, Mishima S and Nozawa Y: Cell growth inhibitory effect of cinnamic acid derivatives from propolis on human tumor cell lines. Biol Pharm Bull 26: 1057-1059, 2003.

52. Yoshida T, Konishi M, Horinaka M, Yasuda T, Goda AE, Taniguchi H, Yano K, Wakada M and Sakai T: Kaempferol sensitizes colon cancer cells to TRAIL-induced apoptosis. Biochem Biophys Res Commun 375: 129-133, 2008.

53. Li X, Wang JN, Huang JM, Xiong XK, Chen MF, Ong CN, Shen HM and Yang XF: Chrysin promotes tumor necrosis factor (TNF)-related apoptosis-inducing ligand (TRAIL) induced apoptosis in human cancer cell lines. Toxicol In Vitro 25: 630-635, 2011.

54. Baritaki S, Militello L, Malaponte G, Spandidos DA, Salcedo M and Bonavida B: The anti-CD20 mAb LFB-R603 interrupts the dysregulated NF- $\kappa \mathrm{B} /$ Snail/RKIP/PTEN resistance loop in B-NHL cells: Role in sensitization to TRAIL apoptosis. Int J Oncol 38: 1683-1694, 2011. 